\title{
Business Cycle Forecasts and their Implications for High Frequency Stock Market Returns
}

\author{
HORST ENTORF, ${ }^{*}$ ANNE GROSS ${ }^{2}$ AND \\ CHRISTIAN STEINER ${ }^{1}$ \\ 1 Department of Economics, Goethe-University Frankfurt, \\ Frankfurt, Germany \\ 2 TU-Darmstadt, Darmstadt, Germany
}

\begin{abstract}
This article contributes to the literature on business cycle forecasts and their impact on asset prices by investigating how the 15 -second Xetra DAX returns reflect the monthly announcements of the two best-known business cycle forecasts for Germany, i.e., the Ifo Business Climate Index and the ZEW Indicator of Economic Sentiment. The analysis disentangles 'good' macroeconomics news from 'bad' news and, simultaneously, considers time intervals with and without confounding announcements from other sources. Releases from both institutes lead to an immediate response of returns occurring 15 seconds after the announcements, i.e. within the first possible time interval. Announcements of both institutes are also clearly and immediately reflected in the volatility, which remains at a significantly higher level for approximately 2 minutes. Findings can be used to improve high-frequency forecasts in stock markets. Copyright (C) 2010 John Wiley \& Sons, Ltd.
\end{abstract}

KEY WORDS high-frequency forecasts; announcement effect; event study

\section{INTRODUCTION}

Many studies have analyzed the predictability of stock market returns and volatility based on macroeconomic variables in the past. Most recently, high-frequency data have enabled new insights into measuring the efficiency of markets and short-term market predictability. There is an increasing amount of literature analyzing macroeconomic announcements and their impact on stock and bond markets as well as exchange rates. Fleming and Remolona (1999) report a two-step price reaction due to macroeconomic news and other public information. After a large price movement Hamelink (2003) finds a persistent trend and a clear rebound some periods after the initial movements. Andersen et al. (2007) show that stock markets react differently to good news than to bad news

\footnotetext{
*Correspondence to: Horst Entorf, Department of Economics, Goethe-University Frankfurt, Grüneburgplatz 1, D-60323

Frankfurt, Germany. E-mail: entorf@wiwi.uni-frankfurt.de

Copyright () 2010 John Wiley \& Sons, Ltd.
} 


\section{H. Entorf, A. Gross and C. Steiner}

depending on the state of economy. Studies on forecasting stock market returns and volatility benefit from the findings on the announcement effect of macro news. For example, Rapach et al. (2005) show that accounting for macroeconomic variables such as interest rates and inflation rates improves the predictability of stock returns. Taylor (2008) verifies that idiosyncratic volatility leads to significant improvements of volatility models, whereas idiosyncratic volatility can also be influenced by macroeconomic information and events. MacMillan and Speight (2004) show that GARCH models can be improved by incorporating cumulative squared returns from intraday data in the volatility equation. In order to gain better understanding of the electronic market price reaction processes, a more recent line of research is studying the dynamics of the limit order book around macroeconomic news. Erenburg and Lasser (2009) show that the quality of the electronic market (measured by higher spreads and lower depth) deteriorates and traders need to follow a more aggressive strategy in response to news releases. Menkvelt et al. (2008) use the order flow following macroeconomic announcements in order to identify causality from customer flow to risk-free rates (and to exclude reverse causality).

The present study contributes to this literature by looking at the German evidence, represented by the German stock market index, DAX, in order to capture additional information in time series being relevant for forecasting purposes. Germany's macroeconomic prospects are pooled and focused in the monthly releases of Germany's two leading business cycle forecasts, namely the Ifo Business Climate Index and the ZEW Indicator of Economic Sentiment. Andersson et al. (2009), studying the impact of macro news and European Central Bank (ECB) monetary policy releases on European bond markets, show that releases of both indicators have a significant impact on long-term German government bond futures contracts. Our study focuses on the stock market and analyzes the reaction of the DAX, which is available with a 15-second frequency upon their publications. Stock market reactions are considered for days without any further simultaneous macroeconomic news from other sources, and for days on which the announcements are made simultaneously along with other confounding news releases (such as announcements of the ECB or by Eurostat). Moreover, in order to account for the potential asymmetry of 'good' and 'bad' news, both are considered, thus separately leading to four different regime categories that need to be distinguished. Results presented in this paper show the implication of monthly releases of business cycle indicators on forecasting DAX returns and volatility. Among others, such short-term forecasts are of particular interest for the exact timing of so-called iceberg orders, where a large order in an electronic order book is automatically split into smaller tranches (see, for example, Esser and Mönch, 2007). ${ }^{1}$

The remainder of the paper is organized as follows. In the next section we describe the forecast predictability of leading German business cycle indicators. The data used in our empirical investigation are illustrated in the third section. The fourth section presents the empirical results. The fourth section examines the DAX return reaction on macroeconomic news and investigates the intraday volatility of the DAX returns on Ifo and ZEW release days; a joint GARCH model for returns and volatility is then presented. The final section summarizes results and outlines the main conclusions.

\footnotetext{
${ }^{1}$ Existence of a macroeconomic announcement has an impact on the optimal trading strategy. As iceberg (hidden) orders have lower priority than regularly displayed orders, they have to be priced more aggressively (Erenburg and Lasser, 2009). Thus traders have to weigh the advantage of placing iceberg orders with the cost of pricing these orders more aggressively during the time period affected by macro news. 
Business Cycle Forecasts Based on High-Frequency Data

\section{USING SURVEY-BASED INDICATORS FOR FORECASTING THE GERMAN BUSINESS CYCLE}

\section{German business cycle indicators}

Apart from the two most popular German business cycle indicators, i.e., the Ifo Business Climate Index and the ZEW Indicator of Economic Sentiment, the Purchasing Manager Index (PMI), ${ }^{2}$ Economic Sentiment Indicator $(\mathrm{ESI})^{3}$ and the sentix Economic Indices for Europe (sentix) ${ }^{4}$ are available.

There have been several studies comparing different German sentiment indicators and their economic forecast ability. Hüfner and Schröder (2002), for instance, compare these sentiment indicators and find that the Ifo, PMI, and ZEW indicators indeed run well ahead of the economic activity in Germany. With respect to the three indicators Ifo, PMI, and ZEW, out-of-sample forecasts suggest that Ifo and ZEW provide the best forecasts. While all five indicators-Ifo, ZEW, PMI, ESI, and sentix-are published monthly, there are significant differences in the publication schedule. The sentix indicator is usually the first to be released, followed by the ZEW indicator and the Ifo index. The ESI release takes place on the last day of the month, whereas the PMI is reported on the first business day of the following month.

The Ifo (Munich) Business Climate Index has now been surveyed for more than 30 years following the same method. According to Sinn and Abberger (2006), the timely persistence as well as the monthly on-time release have created great confidence in the quality of the Ifo index.

A monthly survey questioning approximately 7000 firms in manufacturing, construction, wholesaling, and retailing forms the basis of the Ifo Business Climate Index. ${ }^{5}$ In referring to ordinal responses as $(+,=,-)$, the individual forecasts are aggregated into categories. Both Ifo and ZEW (see below) base their indicators on so-called balances. ${ }^{6}$ The initial release of the Ifo indicator is at 10:00 Central European Time (CET). The forecasting power of the Ifo index has recently been analyzed by Sinn and Abberger (2006). According to them, the qualitative assessment of the strength of the economic situation in combination with the weighted survey results helps in drawing conclusions about the strength of the cyclical growth. The Ifo Business Climate is also very useful in forecasting European economic development. A survey among 30 European economists led by Reuters in early 2005 found the Ifo Business Climate Index to be Europe's most important business indicator. The forecasting power of the Ifo index even outside Germany is due to the high export quota of the German manufacturing industry and the leading role of the German economy in Europe (Sinn and Abberger, 2006).

The ZEW (Mannheim) Indicator of Economic Sentiment is calculated from the results of the ZEW Financial Market Survey. This survey has been carried out monthly since December 1991. It displays the expectations of financial experts for six $^{7}$ important international financial markets. ${ }^{8}$ It is released

\footnotetext{
${ }^{2}$ Calculated and managed by Association Materials Management, Purchasing, and Logistics (AMMPL) since 1996.

${ }^{3}$ Calculated for Germany by the European Commission since 1985.

${ }^{4}$ Calculated by sentix since 2003 .

${ }^{5}$ Most information about the Ifo Business Climate Index mentioned in this section can be found on the Ifo Institute's website (Ifo, 2006).

${ }^{6}$ These are defined as $s=p-m$, where $p$ denotes the relative frequency of the positive categories (+), and $m$ is the relative frequency of the negative categories (-). The balance equals the mean of the responses in the case that the categories are encoded as $+1,0$, and -1 . In terms of out-of-sample forecasting power, Entorf (1993) has shown that balances are easily outperformed by other combinations of,$+=$ and - . In particular, the simple use of the minus share $m$ instead of $s$ would improve forecasting performance.

${ }^{7}$ That is, Germany, USA, Japan, GB, France, and Italy.

${ }^{8}$ See ZEW's website for most information about the ZEW Indicator of Economic Sentiment presented in this section.
} 


\section{H. Entorf, A. Gross and C. Steiner}

online at 11:00 CET on the second or third Tuesday of each month. The ZEW Indicator of Economic Sentiment is a leading indicator for the German economy (similar to the Ifo index). A further indicator, the G-Mind (German Market Indicator), displays the sentiment of the analysts concerning the German stock and bond markets. Both indicators enjoy broad public interest.

\section{A comparison of the Ifo index and the ZEW indicator using monthly data}

Hüfner and Schröder (2002) find that both, ZEW and Ifo indices, have good qualities as leading indicators for the industrial production in Germany. Analyzing correlations and using tests of causality, they provide statistical evidence for the ZEW indicator having a 1-month lead over the Ifo business expectations. Accordingly, both Ifo business expectations and ZEW Indicator of Economic Sentiment show a significant lead compared to industrial output in Germany (ZEW: 6 months; Ifo: 4 months). A direct comparison of the two indicators shows that Ifo performs better in the short run (1 month), whereas the ZEW indicator is superior for medium- to long-term forecasts. A combination of the ZEW indicator and Ifo expectations might improve the forecasting quality for short- and medium-term horizons, given that the two surveys indeed contain complementary information.

An update of their study comparing the forecasting qualities of the ZEW indicator and the Ifo business expectations was released by Hüfner and Schröder (2005). This study confirms the findings of the first study regarding the lead of the ZEW indicator, and the contribution of both indicators to the explanation of industrial production and the forecasting periods.

\section{Stock market efficiency and reactions to macro news}

A potential reason for not finding any statistical significance of announcement effects might be prior leakage of information. Andersson et al. (2009) hint at this widely neglected problem in the academic literature. As regards the German case, using detailed information from European media reports they find that only information of the German unemployment report has been released before the official announcement. However, based on these 'unofficial' release times no significant impact on bond returns have been reported (Andersson et al., 2009). Funke and Matsuda (2006) find a significant surprise component in the German unemployment report, but they argue that international news from the USA might even have a more important impact on the German stock market.

Meanwhile, there are numerous studies reporting significant announcement effects. Moreover, the degree of stock market efficiency measured by the speed of price adjustments seems to increase over time. Patell and Wolfson (1984) report that the main reaction after the announcement of earnings and dividends was completed within 5-15 minutes. Ederington and Lee (1993) show that most of the price adjustment is finished within 1 minute. Most recent contributions (see, for instance, Andersen et al., 2003) find almost immediate reactions of financial markets.

Stock markets are analyzed in terms of both returns and volatility. For more than 20 years research partly focused on the asymmetric impact of good news and bad news. Pearce and Roley (1985) argue that 'good' economic perspectives might trigger increasing interest rates such that rising expected costs of capital would lead to negative stock market returns. Engle and Ng (1993) describe an asymmetric response of volatility to good and bad news, with negative shocks causing higher volatility. The effect of stock market prices to good or bad news depends on the state of the economy (McQueen and Roley, 1993; Boyd et al., 2005; Andersen et al., 2007). Andersen et al.'s (2007) findings suggest that bad macroeconomic news has the expected negative effect on stock prices during recessions but a positive impact during expansions. Concerning both returns and volatility Chulia et al. (2010) find that the magnitude of surprises is more pronounced for good than for bad news. 
The availability of high-frequency data has enabled financial researchers to investigate seasonal phenomena of intraday volatility. Berry and Howe (1994), Goodhart and O'Hara (1997), Jones et al. (1998), and others find that intraday volatility has a U-shaped form, implying that market uncertainty is highest at the beginning and at the end of the trading day. In a recent paper, Harju and Hussain (2006) confirm this finding based on 5-minute returns of the four most important European stock exchanges (CAC40, FT100, SMI, XDAX). Entorf and Steiner (2007) refine the findings about the German DAX using 15-second intervals.

\section{DATA}

Empirical evidence of this paper is based on two leading indicators of the German economy (i.e., the Ifo Business Climate Index and the ZEW Indicator of Economic Sentiment) and Deutscher Aktienindex (DAX) intraday data. The DAX measures the performance of the Prime Standard's 30 largest German companies in terms of order book volume and market capitalization (Deutsche Börse, 2006). Calculation of the index starts at 09:00 CET and ends with documenting prices from the Xetra9 closing auction at 17:30 CET.

The intraday data for our analysis was provided by the Karlsruher Kapitalmarktdatenbank (KKMDB $){ }^{10}$ who obtain their market data directly from Deutsche Börse AG, Frankfurt. The records consist of date, index price, and time. Bid-ask quotes or trading volume data are not provided. ${ }^{11}$

Until the end of 2005, 15-second intervals are the highest available frequency for the German Xetra DAX (XDAX). Since January 2006, the XDAX is computed every second. Thus, for our observation period-2 January 2004 to 28 April 2006; in total, 597 trading days-we base our work on 15-second intervals. To create one uniform sample at 15 -second frequency, only the observations at $\bullet \bullet: \bullet: 00, \bullet \bullet: \bullet: 15, \bullet: \bullet \bullet: 30$, and $\bullet \bullet: \bullet: 45$ are selected for 2 January 2006 to 28 April 2006. The time frame is adjusted from 09:00:30 to 17:30:15 (2040 intervals) in order to keep the number of observations for each interval roughly constant.

\section{RESULTS}

We start by analyzing the DAX return reaction on business cycle forecast indicators. Subsequently, we concentrate on the announcement effect on intraday volatilities and finally conclude by combining results from both analyzing returns and volatilities into comprehensive GARCH models. The method proposed by Andersen et al. (2003) using trigonometric decay functions for time-varying response patterns has been frequently applied in order to account for effects of macroeconomic news on bond (e.g., Andersson et al., 2009) and stock markets (e.g., Harju and Hussain, 2006). These studies are based on 5-minute return series, whereas our study is based on 15-second intervals. Additionally, we do not study the trading process during the whole day but focus on impacts during 60-minute intraday windows. As detailed below, most stock market reactions can be characterized by highly significant amplitudes within the first minute after the news release; time and magnitude of these effects are identified using a semi-parametric (dummy variable) approach (see, for example,

\footnotetext{
${ }^{9}$ Xetra is the name of the electronic trading system.

${ }^{10}$ See http://fmi.fbv.uni-karlsruhe.de.

${ }^{11}$ Thus neither the impact of the bid-ask spread nor volume effects can be analyzed. 


\section{H. Entorf, A. Gross and C. Steiner}

Ederington and Lee, 1993, as well as Erenburg and Lasser, 2009, for similar identification strategies).

\section{The announcement effect of business cycle forecasts on the DAX returns}

After testing for the presence of non-trading effects which turn out to be negligible, an autoregressive moving average (ARMA) model for the returns is fitted. Surprise dummies are included in order to determine at which time intervals the release of macroeconomic announcements shows an effect on the DAX.

Following previous approaches (see, for example, Balduzzi et al., 2001; Hautsch and Hess, 2002; Harju and Hussain, 2006), the return analysis is conducted on the set of all observations on release days, whereas non-release days are excluded. The return in the 15-second interval of one-hour windows release day $t$ is given by

$$
R_{i, t}=\ln \frac{\mathrm{DAX}_{i, t}}{\mathrm{DAX}_{i-1, t}}, \quad i=1, \cdots, 240, t=1, \cdots, 28
$$

It is a common finding that not the announcement per se but the unanticipated news contained in the announcement affects returns on announcement days. We therefore use announcement surprises as the difference between realizations and expected values. ${ }^{12}$ Since our aim is to compare the impact of Ifo and ZEW announcements, we use standardized surprises following Balduzzi et al. (2001). The standardized surprise associated with data at time $t$ is given by

$$
S_{t}=\frac{A_{t}-E_{t}}{\hat{\sigma}} \equiv \frac{\text { index }_{t}-\text { index }_{t-1}}{\hat{\sigma}}
$$

where $A_{t}$ denotes the announced value, $E_{t}$ the expected market value of the indicator at time $t$, and $\hat{\sigma}$ is the sample standard deviation of $\left(A_{t}-E_{t}\right)$. Using standardized news facilitates the comparison of responses to the different news releases. We replace the forecast $E_{t}$ in equation (2) by the index value at time $t-1$. This idea is supported by the fact that research institutes appear to pay only little attention to the release of various forecasts for their indicators. Note also that forecasts of forecasts never capture the entire information available immediately before the announcement, since the information keeps flowing until the macroeconomic indicator is released. 'index' stands for either Ifo or ZEW and $\hat{\sigma}$ denotes the sample standard deviation of Ifo or ZEW, respectively. Henceforth we distinguish between positive $\left(S_{t} \geq 0\right)$ and negative $\left(S_{t}<0\right)$ surprises or, equivalently, between 'good' and 'bad' news.

For both indices, our observation period from 2 January 2004 to 28 April 2006 comprises 15-second data of 28 release days. We focus on a 1-hour interval around the release, i.e., [09:30:0010:30:00) for the Ifo index and [10:30:00-11:30:00) for the ZEW indicator, which results in 6720 observations for each indicator.

Due to the fact that the reactions might be heterogeneous with respect to the valence of news ('good' vs. 'bad'), and in order to correct for confounding news releases from other sources, we distinguish four different situations. First, we summarize release days on which announcements are published along with other competing news, and in a different set of days without potentially con-

\footnotetext{
${ }^{12}$ Note that, in this context, 'expectations' refer to the expected value of the respective index and are not to be confused with the expectations component of the Ifo index. 


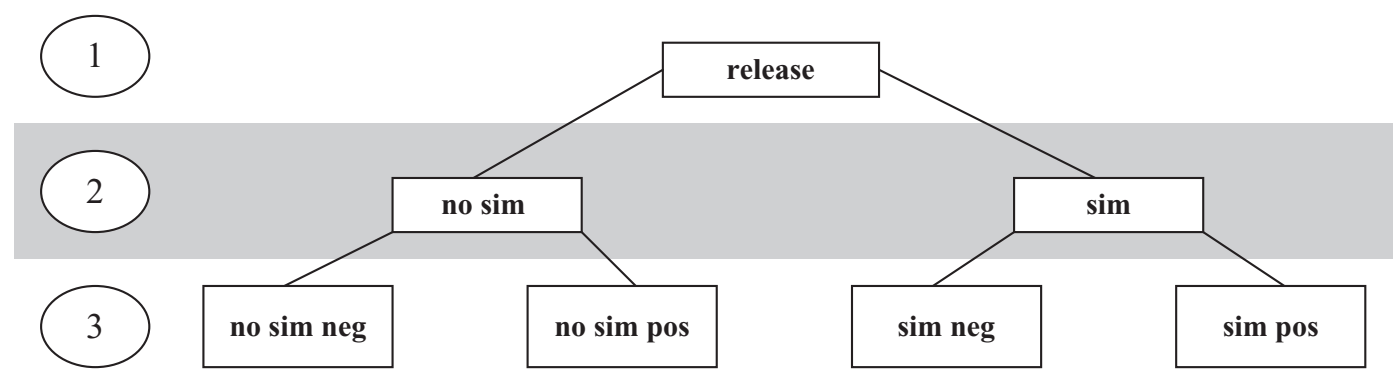

Figure 1. Design of estimation levels based on subsets of release days

founding simultaneous announcements of other macroeconomic indicators. Next, we categorize according to the existence/non-existence of simultaneous news and positive/negative surprises (see also Figure 1 for an illustration):

- 'no sim neg'-refers to days with no simultaneous releases; the released index value reflects 'bad' news (i.e., the index value is lower compared to the previous month);

- 'no sim pos' - denotes days with 'good' news without simultaneous releases from other sources;

- 'sim neg'-indicates 'bad' news on days with simultaneous releases;

- 'sim pos'-reflects positive surprises on days with simultaneous releases.

Our observation period contains 13 Ifo release days with simultaneous announcements by the ECB and 12 out of 28 ZEW release days with simultaneous releases at 11:00 CET, of which 11 are announcements by Eurostat (Statistical Office of the European Communities). ${ }^{13}$ Thus the proportion of days along with and without simultaneous announcements as well as the type of simultaneously released information for Ifo and ZEW are similar.

The goal is to identify significant return reactions (i.e., significant deviations from mean returns) between [09:30:00-10:30:00) on Ifo release days and [10:30:00-11:30:00) on ZEW release days (i.e., 1 hour around the news release). This is done in two steps. First, according to the potential existence of simultaneous releases of confounding macroeconomic news, time intervals with significant return reactions have been pre-selected using evidence from four separate equations for the categories 'no sim neg', 'no sim pos', 'sim neg', and 'sim pos'. In the second stage of the procedure, pre-selected time intervals from the first step are included in an ARMA model of DAX returns:

$$
R_{i, t}=\mathrm{ARMA}+\sum_{J^{+}} \delta_{j}^{+} D_{j, t}^{+} S_{t}+\sum_{J^{-}} \delta_{j}^{-} D_{j, t}^{-} S_{t}+\sum_{\tilde{J}^{+}} \gamma_{j}^{+} \tilde{D}_{j, t}^{+} S_{t}+\sum_{\tilde{J}^{-}} \gamma_{j}^{-} \tilde{D}_{j, t}^{-} S_{t}+\varepsilon_{i, t}
$$

where four groups of dummy variables are considered, namely $D_{j, t}^{+}$indicating significant time intervals for the category ' $n o$ sim $\operatorname{pos}^{\prime}, D_{j, t}^{-}$for 'no sim $n e g^{\prime}, \tilde{D}_{j, t}^{+}$for 'sim pos', and $\tilde{D}_{j, t}^{-}$for 'sim $n e g$ '.

The first-stage pre-selection procedure can be summarized as follows: ${ }^{14}$

\footnotetext{
${ }^{13}$ A detailed list of all simultaneous events is reported in an earlier DP version of this paper (see Entorf et al., 2009).

${ }^{14}$ Details and intermediate results are presented in Entorf et al. (2009).
} 
Table I. Significant $(5 \%)$ return responses within first 5 minutes after announcement

\begin{tabular}{|c|c|c|c|c|c|}
\hline Returns & Ifo & ZEW & & Ifo & ZEW \\
\hline $\begin{array}{l}\text { Good news } \\
\text { No confounding } \\
\quad \text { news }\end{array}$ & $\begin{array}{l}0: 15(+) \\
0: 30(-)\end{array}$ & $\begin{array}{l}0: 15(+) \\
0: 30(+) \\
0: 45(-) \\
1: 15(-) \\
3: 00(-) \\
3: 45(+) \\
4: 15(-) \\
4: 30(-)\end{array}$ & $\begin{array}{l}\text { Bad news } \\
\text { No confounding news }\end{array}$ & None & $\begin{array}{l}0: 15(+) \\
0: 30(+) \\
0: 45(-) \\
1: 30(-) \\
2: 00(-) \\
2: 15(-) \\
3: 45(-)\end{array}$ \\
\hline $\begin{array}{l}\text { Along with } \\
\text { confounding } \\
\text { news }\end{array}$ & $\begin{array}{l}0: 15(+) \\
0: 45(-)\end{array}$ & $\begin{array}{l}0: 15(+) \\
1: 00(-)\end{array}$ & $\begin{array}{l}\text { Along with } \\
\text { confounding news }\end{array}$ & $\begin{array}{l}0: 15(+) \\
0: 30(-) \\
0: 45(+) \\
1: 15(-)\end{array}$ & $\begin{array}{l}0: 15(+) \\
0: 30(+) \\
0: 45(-) \\
1: 15(-) \\
1: 30(-) \\
2: 00(+) \\
2: 30(+)\end{array}$ \\
\hline
\end{tabular}

Note: Positive signs are caused by positive (negative) responses to positive (negative) news; negative signs reflect positive reactions to 'bad' news or negative reactions to 'good' news (see definition of surprise indicator).

(a) For each category an ARMA model is estimated and augmented by a full set of interval dummies; in order to check for robustness the procedure is repeated for 140, 160, 180, 200, 220, and 240 intervals.

(b) All time intervals being significant (at $10 \%$ level) in at least one of the equations under (a) are retained and included in a second round estimate (after excluding all insignificant time intervals).

(c) All intervals still being significant after the second round are captured in $J^{+}, J^{-} \tilde{J}^{+}$and $\tilde{J}^{-}$.

Results reveal a simple $\operatorname{AR}(1)(\rho=0.10)$ for Ifo and a more complex $\operatorname{ARMA}(2,2)$ for ZEW (see Entorf et al., 2009, for details). ARCH tests clearly reject the null hypothesis of no conditional heteroskedasticity which motivates modeling returns as a GARCH process (see below). Significant return reactions are summarized in Table I.

We find that for both institutes there is a first reaction after 15 seconds of time. This response can be characterized as 'immediate', because 10:00:15 and 11:00:15, respectively, coincide with the left margin of the first time interval after the news release at 10:00:00 and 11:00:00, respectively. First reactions of the DAX return to the realization of the surprise variable have the expected positive sign, i.e., the reaction is positive to 'good' news and negative to 'bad' news. ZEW and Ifo differ with respect to the second time interval starting at $\bullet: 00: 30$ : While reactions to ZEW surprises lead to a second upward movement of the DAX, responses to Ifo surprises are negative, indicating an immediate reverse reaction to the first upward movement of the DAX. For ZEW news, this reaction is detected during the next time interval, i.e., at 11:00:45. For Ifo, the reaction seems to be stronger on days with simultaneous announcements of other institutions. On release days without simultaneous announcements (no sim neg, no sim pos), we do not find significant results for Ifo in case of 'bad' news, but rather strong effects for ZEW, whereas in the case of 'good' news reactions to the announcements of both institutes are of similar size. 


\section{Volatility evolution}

In this section similarities and differences of the intraday volatility of the Xetra DAX returns considering Ifo release days and ZEW release days are considered. Our observation period for this analysis comprises all trading days from 2 January 2004 to 28 April 2006 (in total, 597). The volatility is calculated for each 15-second interval from 09:00:30 to 17:30:15 (namely 2040 intervals). However, we do not present results covering the complete trading day, as no differences to the analysis of intraday seasonalities by Harju and Hussain (2006) and Entorf and Steiner (2007) have been identified.

For our analysis the volatility of the time interval $i$ at day $t$ is given by

$$
V_{i, t}=\left|R_{i, t}-\bar{R}_{i}\right|
$$

where $R_{i, t}$ denotes the Xetra DAX return for time interval $i$ at day $t$ and $\bar{R}_{i}=\frac{1}{T_{i}} \sum_{t=1}^{T_{i}} R_{i, t}$ is the average return for time interval $i$ over all trading days. The average intraday volatility for each interval $I$ $(i=1, \ldots, 2040)$ is formulated as

$$
\bar{V}_{i}=\frac{1}{T_{i}} \sum_{t=1}^{T_{i}} V_{i, t}
$$

where $T_{i}$ is the number of observations for interval $i$ with respect to the period under review. ${ }^{15}$

Subsequent GARCH models (see below) are based on the time interval around the release of the Ifo index, namely [09:30:00-10:30:00) and the ZEW indicator, namely [10:30:00-11:30:00). Figure 2 provides volatility graphs of the 1-hour window around the publication date, where the upper plot compares the volatility on Ifo release and non-release days and the lower panel offers volatility graphs on ZEW release and nonrelease days. Both the Ifo and ZEW releases are clearly reflected in the market volatility, which remains elevated for approximately 2 minutes. Thus volatility reactions seem to be more persistent than return reactions. The peaks are even more pronounced for the ZEW release than for the Ifo release.

\section{Modeling returns and volatility using a GARCH model}

This section summarizes previous insights and introduces a joint model for returns and volatility around the release of the Ifo index and the ZEW indicator, respectively. Starting from the initial ARMA-setting derived above, we add to the complexity of our return model by extending the previous ARMA models to a GARCH model. As for the return analysis, we limit our 15-second data to the 28 Ifo (ZEW) release days registered for our observation period from 2 January 2004 to 28 April 2006. Again, we focus on 1-hour intervals around the respective releases, i.e., [09:30:00-10:30:00) for the Ifo index and [10:30:00-11:30:00) for the ZEW indicator. Thus our sample consists of 6720 observations for Ifo and ZEW, respectively.

The extended GARCH model with dummies included in the mean and variance equation can thus be stated as follows:

\footnotetext{
${ }^{15}$ Alternatively, we tried a volatility measure based on $\left(R_{i, t}-\bar{R}_{i}\right)^{2}$. The two volatility measures exhibit similar behavior and appear to follow identical regularities. 

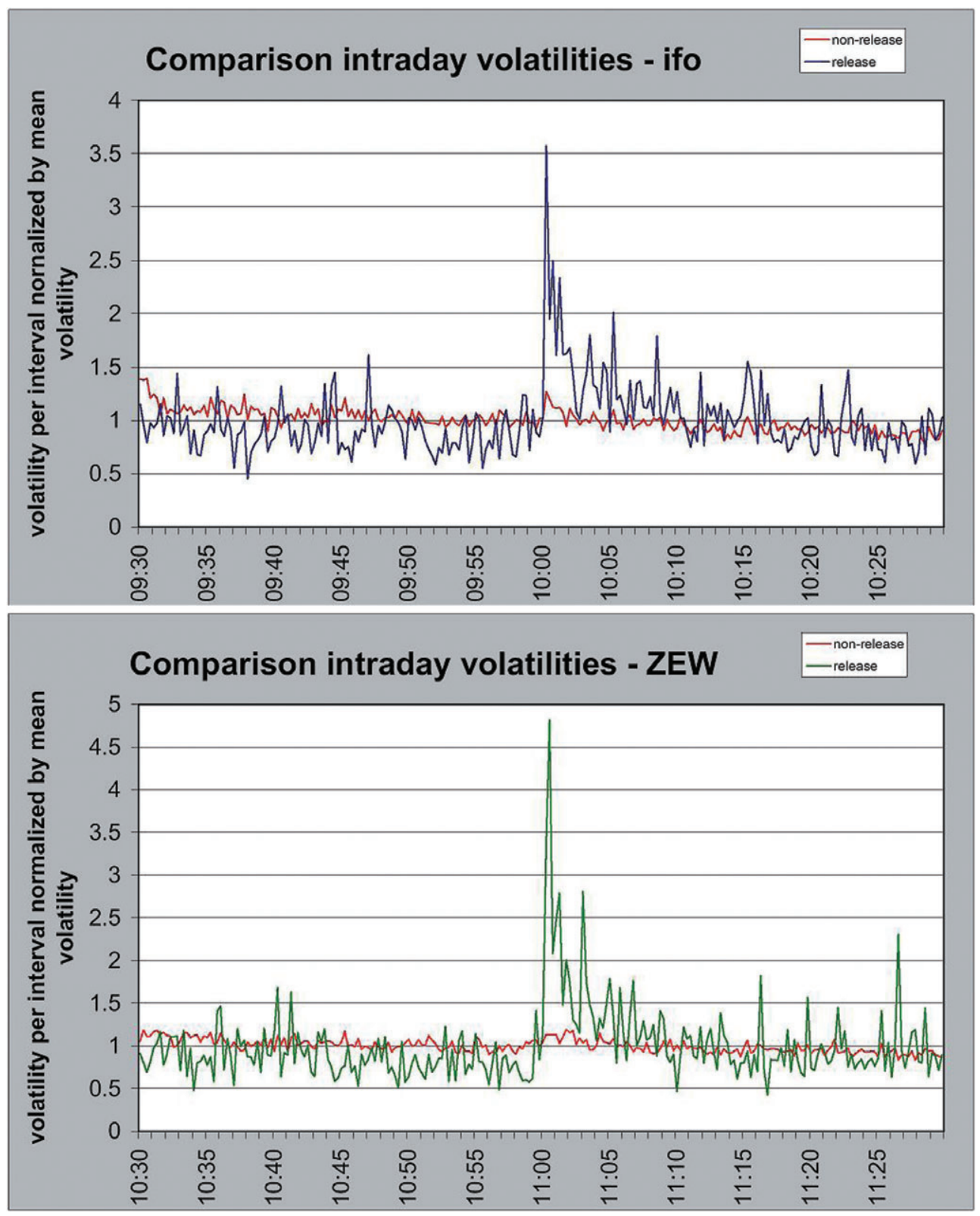

Figure 2. Ifo/ZEW-caused volatility $\bar{V}_{i} / \bar{V}$ for 15 -second intervals. This figure is available in colour at www. interscience.wiley.com/journal/for 


$$
\begin{gathered}
R_{i, t}=\mathrm{ARMA}+\sum_{J^{+}} \delta_{j}^{+} D_{j, t}^{+} S_{t}+\sum_{J^{-}} \delta_{j}^{-} D_{j, t}^{-} S_{t}+\sum_{\tilde{J}^{+}} \gamma_{j}^{+} \tilde{D}_{j, t}^{+} S_{t}+\sum_{\tilde{J}^{-}} \gamma_{j}^{-} \tilde{D}_{j, t}^{-} S_{t}+\varepsilon_{i, t} \\
\sigma_{i, t}^{2}=\lambda+\mu \varepsilon_{i-1, t}^{2}+v \sigma_{i-1, t}^{2}+\sum_{k \in K} \vartheta_{1, k} D_{k, t}+\sum_{k \in \tilde{K}} \vartheta_{2, k} \tilde{D}_{k, t} \\
\varepsilon_{i, t}=u_{i, t} \sigma_{i, t} \\
\begin{array}{c}
\text { i.i.j. } \\
u_{i, t} \sim
\end{array}(0,1) \\
i=1, \ldots 240, \quad t=1, \ldots 28
\end{gathered}
$$

In addition to previous return equations, equation (6) includes two groups of dummies in the variance equation, namely $D_{k, t}$ for release days without simultaneous releases, and $\tilde{D}_{k, t}$ for days with simultaneous releases at 10:00 CET (these dummies again equal 1 only for interval $k$ and are zero elsewhere). Included intervals have been pre-selected following the procedure presented above (see Entorf et al., 2009, for details).

Estimation of model (6) reveals that the added $\operatorname{GARCH}(1,1)$ coefficients $\mu$ and $v$ are significant

\begin{tabular}{|c|c|c|c|c|c|}
\hline Returns & Ifo & ZEW & & Ifo & ZEW \\
\hline \multirow[t]{2}{*}{ No confounding news } & $\begin{array}{l}0: 15(+) \\
0: 30(-)\end{array}$ & $0: 15(+)$ & $\begin{array}{l}\text { Bad news } \\
\text { No confounding } \\
\text { news }\end{array}$ & None & $0: 15(+)$ \\
\hline & & $0: 45(-)$ & & & $0.45(-)$ \\
\hline \multirow[t]{3}{*}{$\begin{array}{l}\text { Along with } \\
\text { confounding news }\end{array}$} & $\begin{array}{l}0: 15(+) \\
0: 45(-)\end{array}$ & $\begin{array}{l}4: 15(-) \\
0: 15(+)\end{array}$ & $\begin{array}{l}\text { Along with } \\
\text { confounding } \\
\text { news }\end{array}$ & $\begin{array}{l}0: 15(+) \\
0: 30(-)\end{array}$ & \\
\hline & & & & & $\begin{array}{l}0: 30(+) \\
0: 45(-)\end{array}$ \\
\hline & & $1: 00(-)$ & & & $\begin{array}{l}1: 30(-) \\
2: 00(+) \\
2: 45(-)\end{array}$ \\
\hline Variance & Ifo & ZEW & & & \\
\hline No confounding news & None & $3: 00(+)$ & & & \\
\hline \multirow{2}{*}{$\begin{array}{l}\text { Along with } \\
\text { confounding news }\end{array}$} & $0: 15(+)$ & $0: 15(+)$ & & & \\
\hline & $0.45(+)$ & $\begin{array}{l}1: 00(+) \\
2: 15(-)\end{array}$ & & & \\
\hline
\end{tabular}
at the $1 \%$ level (results not reported). A concluding comparison of reactions to Ifo and ZEW releases based on GARCH results is presented in Table II. It documents all highly significant (5\%) responses within the first 5 minutes after the respective announcements. Most return reactions are characterized

Table II. Significant (5\%) GARCH responses within the first 5 minutes after announcement

Note: Positive signs are caused by positive (negative) responses to positive (negative) news; negative signs reflect positive reactions to 'bad' news or negative reactions to 'good' news (see definition of surprise indicator).

Copyright $@ 2010$ John Wiley \& Sons, Ltd.

J. Forecast. (2011)

DOI: $10.1002 /$ for 


\section{H. Entorf, A. Gross and C. Steiner}

by a fast response after 15 seconds, followed by a counter-reaction after 30-45 seconds. For 'good' news, there is an upward movement for both institutes after 15 seconds, irrespective of the presence of confounding announcements. The picture is less clear for 'bad' news, as there is no significant reaction to announcements of the Ifo Institute, at least in the absence of confounding information. ZEW announcements seem to cause some further stock market adjustments, since responses are not limited to the first 60 seconds but also some significant ups and downs can be observed thereafter.

The immediate reactions at 11:00:15 (Ifo) and 10:00:15 (ZEW) can be observed for the variance equation too, but only in the absence of confounding announcements. Moreover, looking at the broader picture reveals that counter-reactions are less important than further positive outliers (at 00:45 for Ifo and 01.00 for ZEW), confirming the generally increased volatility levels in response to business cycle forecasts shown in Figure 2.

\section{SUMMARY AND CONCLUSIONS}

This article contributes to the literature on business cycle forecasts and their impact on asset prices by investigating how the 15-second Xetra DAX returns reflect the monthly announcements of the two best-known business cycle forecasts in Germany, i.e., the Ifo Business Climate Index and the ZEW Indicator of Economic Sentiment. From the methodological point of view, the main focus lies in disentangling 'good' macroeconomics news from 'bad' news and, simultaneously, considering time intervals with and without confounding announcements from other sources.

We find that responses to forecasts reveal an immediate impact at 15 seconds after the announcements of both Ifo and ZEW: positive (negative) news results in an immediate increase (decrease) of returns. Moreover, a first counter-movement becomes apparent at 30 seconds for Ifo and at 45 seconds for ZEW. In general, the impact of 'positive' news appears to be faster and stronger than the impact of 'bad' news. A detailed volatility analysis is conducted for the 1-hour interval around the Ifo and ZEW releases. We find the respective announcement (i.e., Ifo or ZEW) to be clearly and immediately reflected in the volatility, which remains at a significantly higher level for approximately 2 minutes. Finally, we proceed with a combined modeling of returns and volatility in a $\operatorname{GARCH}(1,1)$ model. Results reveal that significant increases in volatility only show up in the presence of simultaneous news released by other sources, whereas return reactions can be observed irrespective of whether confounding announcements are present or not.

Aiming at explaining the somewhat less pronounced return reaction to Ifo announcements compared to the reaction to ZEW releases, we suppose that this result might be caused by the earlier publication of the ZEW indicator. According to Andersen et al. (2003), early announcements within the same category of macroeconomic indicators exhibit greater impact than those released later, as the impact of new information diminishes if major components of the release are already known or may be forecast from other previously released figures. Since the ZEW value for the current month is already known to the market when the Ifo index is released (Ifo forecasts are published during the last week of the month, whereas ZEW news are released during the second or third week), any change of the Ifo surprise variable might already be priced by financial markets.

Given the better short-run forecasting performance of Ifo compared to the ZEW indicator mentioned in the literature, the Ifo qualifies to be accounted for in 1-month horizon forecasts, whereas the ZEW indicator is superior for medium-term forecasts (year-on-year). Presented findings add to this knowledge, because both indicators can improve validity and reliability of high-frequency models. Knowledge of the impact of macro news is also important for understanding the price 
dynamics related to the limit order book and for designing optimal trading strategies, e.g., with respect to the placement of hidden (iceberg) orders (see Erenburg and Lasser, 2009).

Future research should focus on the reasons for the regular pattern of counter-reactions found after 30 and 45 seconds. Some hints might be found in the problem of overshooting, but also research on reactions caused by changing interest rates in anticipation of future money demand is of related interest.

\section{ACKNOWLEDGEMENTS}

Earlier versions of the paper have been presented at the International Conference on High Frequency Finance in Constance, at the annual meeting of the German Economic Association ('Verein für Socialpolitik') in Graz and at the CIRET workshop on Sentiment Indicators and the Current Crisis in Budapest. We wish to thank Siem Jan Koopman, an anonymous referee, conference participants as well as Birgit Herrmann for useful comments and suggestions.

\section{REFERENCES}

Andersen TG, Bollerslev T, Diebold FX, Vega C. 2003. Micro effects of macro announcements: real-time price discovery in foreign exchange? American Economic Review 93(1): 38-62.

Andersen TG, Bollerslev T, Diebold FX, Vega C. 2007. Real-time price discovery in global stock, bond and foreign exchange markets. Journal of International Economics 73: 251-277.

Andersson M, Overby LJ, Sebestyen S. 2009. Which news moves the euro area bond market? German Economic Review 10(1): 1-31.

Balduzzi P, Elton EJ, Green TC. 2001. Economic news and bond prices: evidence from the U.S. Treasury market. Journal of Financial and Quantitative Analysis 36(4): 523-543.

Berry TD, Howe KM. 1994. Public information arrival. Journal of Finance 49(4): 1331-1346.

Bloom N. 2009. The impact of uncertainty shocks. Econometrica 77(3): 623-685.

Boyd JH, Jagannathan R, Hu J. 2005. The stock market's reaction to unemployment news: why bad news is usually good for stocks. Journal of Finance 60(2): 649-672.

Chulia H, Martens M, Van Dijk D. 2010. Asymmetric effects of federal funds target rate changes on S\&P100 stock returns, volatilities and correlations. Journal of Banking and Finance 34: 834-839.

Deutsche Börse. 2006. Deutsche Börse Group. Available: http://deutsche-boerse.com [5 November 2010].

Ederington LH, Lee JH. 1993. How markets process information: news releases and volatility. Journal of Finance 48(4): 1161-1191.

Engle RF, Ng VK. 1993. Measuring and testing the impact of news on volatility. Journal of Finance 48(5): 1749-1778.

Entorf H. 1993. Constructing leading indicators from non-balance sectoral business survey series. International Journal of Forecasting 9(2): 211-225.

Entorf H, Steiner C. 2007. Makroökonomische Nachrichten und die Reaktion des 15-Sekunden-DAX: Eine Ereignisstudie zur Wirkung der ZEW Konjunkturprognose. Jahrbücher für Nationalökonomie und Statistik 227(1): 2-26.

Entorf H, Gross A, Steiner C. 2009. Return and volatility reactions to monthly announcements of business cycle forecasts: an event study based on high-frequency data. ZEW discussion paper 09-010.

Erenburg G, Lasser D. 2009. Electronic limit order book and order submission choice around macroeconomic news. Review of Financial Economics 18: 172-182.

Esser A, Mönch B. 2007. The navigation of an iceberg: the optimal use of hidden orders. Finance Research Letters 4(2): $68-81$.

Fleming MJ, Remolona EM. 1999. Price formation and liquidity in the U.S. Treasury market: the response to public information. Journal of Finance 54(5): 1901-1915.

Copyright () 2010 John Wiley \& Sons, Ltd.

J. Forecast. (2011)

DOI: $10.1002 /$ for 


\section{H. Entorf, A. Gross and C. Steiner}

Funke N, Matsuda A. 2006. Macroeconomic News and Stock Returns in the United States and Germany. German Economic Review 7(2): 189-210.

Goodhart CAE, O'Hara M. 1997. High frequency data in financial markets: issues and applications. Journal of Empirical Finance 4: 73-114.

Hamelink F. 2003. Systematic patterns before and after large price changes: evidence from high frequency data from the Paris bourse. Journal of Forecasting 22: 533-549.

Harju K, Hussain SM. 2006. Intraday seasonalities and macroeconomic news announcements. Working Paper 512, Swedish School of Economics and Business Administration. Available: http://ideas.repec.org/p/hhb/hanken/0512. html [5 November 2010].

Hautsch N, Hess D. 2002. The processing of non-anticipated information in financial markets: analyzing the impact of surprises in the employment report. European Finance Review 6: 133-161.

Hüfner FP, Schröder M. 2002. Prognosegehalt von ifo-Geschäftserwartungen und ZEW-Konjunkturerartungen: Ein ökonometrischer Vergleich. Jahrbücher für Nationalökonomie und Statistik 222(3): 316-336.

Ifo. 2006. CESifo Group Munich Homepage: Ifo Institute, CES, CESifo GmbH. Available: http://www. cesifo-group.de [5 November 2010].

Jones C, Lamont O, Lumsdaine R. 1998. Macroeconomic news and bond volatility. Journal of Financial Economics 47: 427-445.

MacMillan D, Speight AEH. 2004. Daily volatility forecasts: reassessing the performance of GARCH models. Journal of Forecasting 23: 449-460.

McQueen G, Roley VV. 1993. Stock prices, news, and business conditions. Review of Financial Studies 6(3): 683-707.

Menkveld AJ, Sarkar A, Van der Wel M. 2008. Customer flow, intermediaries, and the discovery of the equilibrium riskfree rate, EFA 2007 Ljubljana Meetings Paper: FRB of New York Staff Report No. 307. Available: http:// ssrn.com/abstract $=966059$ [5 November 2010].

Patell JM, Wolfson MA. 1984. The intraday speed of adjustment of stock prices to earnings and dividend announcements. Journal of Financial Economics 13: 223-252.

Pearce DK, Roley VV. 1985. Stock prices and economic news. Journal of Business 58(1): 49-67.

Rapach D, Wohar M, Rangvid J. 2005. Macro variables and international stock return predictability. International Journal of Forecasting 21: 137-166.

Schmidt S, Schröder M. 2005. Prognosevergleich der ZEW-Konjunkturerwartungen und der ifoGeschäftserwartungen: Eine Aktualisierung, ZEW Wachstums- und Konjunkturanalysen, Zentrum für Europäische Wirtschaftsforschung (ZEW), Mannheim. Available: ftp://ftp.zew.de/pub/zew-docs/div/ Prognoseguete_konj_0502.pdf. [18 November 2010].

Sinn H-W, Abberger K. 2006. Zur Prognosekraft des ifo Indikators: Ifo Schnelldienst 4, Ifo Institute for Economic Research. Available: http://www.cesifo-group.de/link/ifosd_2006_4_6.pdf [5 November 2010].

Taylor N. 2008. Can idiosyncratic volatility help forecast stock market volatility? International Journal of Forecasting 24: 462-479.

Authors' biographies:

Horst Entorf is professor of econometrics at Goethe University Frankfurt, Germany. His research interests include applied econometrics, analysis of survey data and survey based forecasts.

Anne Gross studied Mathematics at the Department of Mathematics at Darmstadt University of Technology, Germany. Currently, she works as a Statistician for an international company.

Christian Steiner holds a joint Master degree of mechanical engineering and management from Darmstadt University of Technology. Currently he is preparing his $\mathrm{PhD}$ thesis on survey-based forecasts at Goethe University Frankfurt, Germany.

Authors' addresses:

Horst Entorf and Christian Steiner, Department of Economics, Goethe-University Frankfurt, Grüneburgplatz 1, D-60323 Frankfurt, Germany.

Anne Gross, TU-Darmstadt, Marktplatz 15, D-64283 Darmstadt, Germany. 